\title{
Hepatopulmonary Syndrome and Liver Transplantation: A Recent Review of the Literature
}

\author{
Caglar Cosarderelioglu ${ }^{1}$, Arif M. Cosar ${ }^{1}$, Merve Gurakar $^{2}$, Nabil N. Dagher $^{3}$ \\ and Ahmet Gurakar*1 \\ ${ }^{1}$ Johns Hopkins University School of Medicine, Department of Gastroenterology/Hepatology, Baltimore, MD, USA; ${ }^{2}$ Virginia \\ Commonwealth University School of Medicine, Richmond, VA, USA; ${ }^{3}$ Johns Hopkins University School of Medicine,
} Department of Surgery/Liver Transplant, Baltimore, MD, USA

\begin{abstract}
A severe and common pulmonary vascular complication of liver disease is hepatopulmonary syndrome (HPS). It is a triad of liver dysfunction and/or portal hypertension, intrapulmonary vascular dilatations, and increased alveolar-arterial oxygen gradient. Prevalence varies according to various study groups from $4 \%-47 \%$. While the most common presenting symptom of HPS is dyspnea, it is usually asymptomatic, and thus all liver transplant candidates should be screened for its presence. Pulse oximetry is a useful screening method, but arterial blood gas examination is the gold standard. If there is an abnormal $\mathrm{P}(\mathrm{A}-\mathrm{a}) \mathrm{O}_{2}$ gradient, microbubble transthoracic echocardiography should be done for diagnosis. Outcome is unpredictable, and there is currently no effective medical therapy. The only effective therapy is considered to be liver transplantation. Complete resolution of HPS after liver transplantation is seen within a year in most HPS patients. (C) 2016 The Second Affiliated Hospital of Chongqing Medical University. Published by XIA \& HE Publishing Inc. All rights reserved.
\end{abstract}

\section{Introduction}

There are three main pulmonary conditions in patients with liver disease and/or portal hypertension. These are hepatopulmonary syndrome (HPS), portopulmonary hypertension (PoPH), and hepatic hydrothorax. Portopulmonary hypertension is a pulmonary hypertension that develops due to portal

Keywords: Hepatopulmonary syndrome; Pulmonary complications of cirrhosis; Liver transplantation.

Abbreviations: $A B G$, arterial blood gas; $C B D L$, common bile duct ligation; $C O$, carbon monoxide; $\mathrm{CT}$, computed tomography; $\mathrm{ET}$, endothelin; HPS, hepatopulmonary syndrome; HO, heme oxygenase; iNOS, inducible NOS; IPVD, intrapulmonary vascular dilation; L-NAME, N(G)-nitro-L-arginine methyl ester; LT, liver transplantation; MAA scan, macro-aggregated albumin scan; MELD, model endstage liver disease; MTTE, microbubble transthoracic echocardiography; NO nitric oxide; NOS, NO synthase; PoPH, portopulmonary hypertension; PTX, pentoxifylline; PVR, pulmonary vascular resistance; SA, spider angioma; TEE, transesophageal echocardiogram; TGF $\beta-1$, transforming growth factor beta-1; TIPS, transjugular intrahepatic portosystemic shunt; $\mathrm{TNF} \alpha$, tumor necrosis factor alpha; TTE, transthoracic echocardiogram; VEGF, vascular endothelial growth factor; ZnPP, zinc protoporphyrin.

Received: 24 November 2015; Revised: 10 February 2016; Accepted: 11 February 2016

DOI: $10.14218 / \mathrm{JCTH} .2015 .00044$

*Correspondence to: Ahmet Gurakar, 720 Rutland Avenue, Ross Research Building, Suite \#918, Baltimore, Maryland, 21205, USA, Tel: 410-614-3369, Fax: 410-367-2328, E-mail: aguraka1@jhmi.edu hypertension with or without liver disease. Hepatic hydrothorax is a pleural effusion in a cirrhotic patient without cardiac, pulmonary, or pleural disease.

HPS is caused by hyperdynamic circulation, intrapulmonary shunts, and pulmonary vasodilatation. It is a triad of liver dysfunction and/or portal hypertension, intrapulmonary vascular dilatations, and increased alveolar-arterial oxygen gradient ( $>15 \mathrm{~mm} \mathrm{Hg}$ or $>20 \mathrm{mmHg}$ when age $\geq 65$ years).$^{1}$ Fluckiger first described a relationship between HPS and cirrhosis on a female patient with cyanosis and cirrhosis in 1884, but Kennedy and Knudson named the situation "Hepatopulmonary Syndrome" in $1977 .{ }^{2}$ HPS is usually associated with portal hypertension with or without cirrhosis, but it can occur also in patients with acute or chronic hepatitis, ${ }^{3-5}$ hypoxic hepatitis, ${ }^{6}$ extrahepatic obstruction, Budd-Chiari Syndrome, ${ }^{7}$ and cavopulmonary shunts. ${ }^{8}$

The incidence of HPS is higher than PoPH, and both of them are associated with significantly increased morbidity and mortality. Their pathophysiologies, however, are completely different. HPS is characterized by vasodilatation and intrapulmonary shunts, whereas PoPH is caused by pulmonary vasoconstriction and increased pulmonary vascular resistance (PVR). Despite this difference, both can be seen in the same patient, with $\mathrm{PoPH}$ developing generally after HPS. ${ }^{9,10}$ One theory for this mechanism involves dysregulation of the common vascular signaling pathway for pulmonary dilatations and pulmonary arterial remodeling. ${ }^{10} \mathrm{~A}$ second theory involves differences in the expression of the endothelin-1 (ET1) receptor $A$, which causes vasoconstriction and increased pulmonary vascular resistance, and receptor $B$, which leads to upregulation of endogenous nitric oxide synthase and increased nitric oxide production, resulting in pulmonary vasodilation. ${ }^{11}$ Medical treatment cannot cure these conditions, so both have serious implications for liver transplantation (LT). After LT, HPS usually resolves, but the response of PoPH is unpredictable. ${ }^{1}$ All patients on the LT waiting list should be screened for HPS and PoPH because both are commonly asymptomatic.

In this review, we provide an overview on the prevalence, pathophysiology and pathogenesis, clinical signs, and prognosis of HPS as well as the currently available treatment options for HPS, especially LT.

\section{Prevalence}

The prevalence of HPS varies from $4 \%$ to $47 \%$, depending on the population and the criteria used to diagnose. ${ }^{12-15}$ 
Intrapulmonary vascular dilatations (IPVD) occur among $13 \%-80 \%$ of LT candidates, ${ }^{16}$ but arterial blood gas abnormalities do not develop in all patients. Abrams et al., detected IPVD in $38.0 \%$ of cirrhotic patients, however, they reported gas abnormalities among only $17.5 \%$ of them. ${ }^{17}$ These finding suggest that mild IPVDs do not always cause gas exchange abnormalities. There is no reported association between severity of liver disease and severity of HPS. ${ }^{17-19}$

\section{Pathophysiology and Pathogenesis}

The main mechanism of HPS is impaired gas exchange, ventilation-perfusion mismatch by intrapulmonary capillary vasodilatation, and arteriovenous shunts. ${ }^{1}$ Pulmonary blood flow increases due to pulmonary vasodilatation and hyperdynamic circulation in liver disease. These changes also cause a decrease in the transit time of red blood cells in pulmonary capillaries, and oxygen molecules pass a longer distance in a shorter time. Therefore, red blood cells exit from pulmonary capillaries before full oxygenation, and ventilation-perfusion mismatch occurs. ${ }^{20}$ Another reason for hypoxemia is arteriovenous shunting due to vasodilatation and angiogenesis. ${ }^{21}$

\section{Pulmonary vasodilatation}

Much of the information on the pathogenesis of HPS is based on studies on an animal model of cirrhosis created by common bile duct ligation (CBDL). Animal and human studies have shown that excess production of pulmonary vasodilators like nitric oxide (NO) and carbon monoxide (CO) cause HPS and that pulmonary arterial vasodilation arises due to the imbalance between vasodilators and vasoconstrictors. In these CBDL animal models, first, cholangiocytes proliferate and then produce and secrete ET- $1^{22-27}$ due to stimulation by transforming growth factor beta-1 $(T G F \beta-1) .{ }^{28}$ This increase in ET-1 can cause both vasodilatation and vasoconstriction. ${ }^{11}$ When ET-1 binds to its receptor, which is called the ET-1B-receptor, it causes activation of pulmonary endothelial NO synthase (eNOS), and this leads to NO mediated pulmonary vasodilatation. ${ }^{26,29}$ Interestingly, the ET-1B receptor has been shown to be selectively upregulated in experimental portal hypertension. ${ }^{26,29}$

ET-1 also initiates the accumulation of pulmonary intravascular monocytes. ${ }^{30}$ Selective ET-1B receptor blockade or genetic depletion decreases pulmonary eNOS associated NO activation and prevents the onset of HPS. ${ }^{31,32}$ In CBDL animal models, macrophages that adhere to the pulmonary endothelium produce inducible NOS (iNOS), which can also contribute to local NO production. ${ }^{33}$ Exhaled levels of NO were measured in different studies, and after LT, these levels were shown to normalize. ${ }^{34,35}$ Administration of methylene blue was demonstrated to improve transiently oxygenation by inhibiting the action of NO. ${ }^{36-38}$

Carbon monoxide ( $\mathrm{CO}$ ) is another gas that is responsible for pulmonary artery vasodilatation. Levels of arterial carboxyhemoglobin seem to be elevated in HPS patients, ${ }^{39}$ and $\mathrm{CO}$ is produced from the degradation of heme by heme oxygenase (HO). HO has two forms, which are called inducible ( $\mathrm{HO}-1)$ and constitutive (HO-2). ${ }^{25}$ Intravascular macrophages that progressively accumulate after $\mathrm{CBDL}$ produce $\mathrm{HO}-1$, and they cause vasodilatation. ${ }^{25,33,40}$ A specific $\mathrm{HO}-1$ enzyme inhibitor, zinc protoporphyrin IX (ZnPP), decreases intrapulmonary vasodilatation and when it is used in treatment, it improved HPS in animal models of CBDL. ${ }^{41}$
The second mechanism of pulmonary vasodilatation is bacterial translocation and endotoxemia, which trigger recruitment and activation of macrophages in the pulmonary vascular network. ${ }^{42-44}$ These macrophages produce proinflammatory cytokines, like tumor necrosis factor alpha (TNF $\alpha)$, leading to NO mediated vasodilatation. ${ }^{45}$ Pentoxifylline (PTX) is a non-specific TNF $\alpha$, iNOS, and angiogenesis inhibitor. Administration of pentoxifilline has been shown to improve HPS in a rat model of cirrhosis. ${ }^{46,47}$

\section{Pulmonary angiogenesis}

Although vasodilatation is an important factor for HPS, inhibition of NO failed to improve gas exchange in some patients, so it cannot be the only mechanism for HPS. ${ }^{48}$ Vascular endothelial growth factor (VEGF)-mediated angiogenesis ${ }^{49}$ and increased pulmonary capillary density in the CBDL animal model contribute to collateral formation. ${ }^{50}$ These findings suggest that angiogenesis plays a role in HPS pathogenesis. Inflammatory cells accumulate in the lungs by bacterial translocation, endotoxemia, and increased circulating TNF- $\alpha$ due to decreased liver function and inflammation post-CBDL. ${ }^{46,50,51}$ Abnormal intrapulmonary accumulation of monocytes and activated macrophages trigger activation of VEGF signaling pathways, and this causes pulmonary angiogenesis. ${ }^{51}$ It was shown that CD68+ macrophages accumulate in the lungs from rats with HPS and that the histological and hemodynamic features of HPS get better when these macrophages deplete. ${ }^{50}$ In addition, it was demonstrated that there was a decrease in intrapulmonary shunt fraction and a decrease in the $\mathrm{P}(\mathrm{A}-\mathrm{a}) \mathrm{O}_{2}$ gradient by TNF- $\alpha$ neutralization. ${ }^{46,52}$ Endothelial activation of the circulating chemokine ligand 1 (fractalkine, CX3CL1) in the lung may play a role in mediating intrapulmonary accumulation of monocytes and induction of angiogenesis in experimental HPS. ${ }^{53,54}$ Some studies showed that anti-angiogenesis therapy reduced the severity of $\mathrm{HPS}^{55}$ and improved gas exchange and intrapulmonary shunting. ${ }^{22}$

\section{Clinical signs}

HPS is usually asymptomatic, but the most frequent symptoms of HPS are progressive dyspnea and cyanosis. ${ }^{56-57}$ Fatigue, spider naevi, digital clubbing, platypnea, and orthodeoxia are other symptoms of HPS. ${ }^{58}$ None of these signs are specific for HPS; and if a liver disease patient presents with both hypoxemia and digital clubbing, HPS should be eliminated. ${ }^{59}$ Dyspnea and hypoxemia worsen in the upright position due to vasodilatation in the basal parts of the lung, leading to an increase in ventilation-perfusion mismatch. ${ }^{58}$ Orthodeoxia is defined as a decreased partial pressure of arterial oxygen $\left(\mathrm{PaO}_{2}\right)$ from supine to upright position, and it is related with increased intrapulmonary shunting and vascular dilatations in HPS. ${ }^{60}$ Spider angioma (SA) can be a skin marker of HPS, since patients with SA are more hypoxemic in comparison to those who do not have SA. This can be due to the same imbalance between vasodilators and vasoconstrictors. ${ }^{61}$ Usually, oxygen desaturation occurs during sleep in HPS patients, and the degree of hypoxemia correlates with the severity of HPS. ${ }^{62}$ Other physical signs, such as cirrhosis and portal hypertension, can be seen in patients with HPS. 
Cosarderelioglu C. et al: Hepatopulmonary syndrome and liver transplantation

\section{Diagnosis}

When there is a patient with liver disease who shows clinical manifestations of HPS, arterial oxygenation and pulmonary dilatation should be assessed. Pulmonary function tests and imaging should also be done to investigate concomitant lung disease because HPS can coexist with other pulmonary or cardiac diseases and exacerbate symptoms and hypoxemia. ${ }^{63}$ HPS is usually asymptomatic, so all liver transplant centers should routinely screen patients for HPS.

HPS diagnosis consists of a triad (Table 1): the presence of liver disease and/or portal hypertension, elevated room air alveolar-arterial oxygen gradient $\left[\mathrm{P}(\mathrm{A}-\mathrm{a}) \mathrm{O}_{2}\right.$ gradient $]>15$ $\mathrm{mmHg}$ or $>20 \mathrm{mmHg}$ when age $\geq 65$ years], and evidence of IPVD, especially in the basal parts of the lungs. The European Respiratory Society Task Force in 2004 classified HPS according to stage. ${ }^{1}$ The importance of staging is discussed below.

\section{Intrapulmonary Vasodilatation}

Microbubble transthoracic echocardiography (MTTE), nuclear lung scanning (99m-Technetium-labelled macro-aggregated albumin scan, MAA scan), and rarely pulmonary angiography and high-resolution computed tomography (CT) can be used for detection of IPVD. MTTE is considered for the diagnosis of HPS. ${ }^{1,17,64}$ For MTTE, agitated saline with microbubbles with a diameter $>10 \mu \mathrm{m}$ are injected into peripheral vein in the arm. ${ }^{65,66}$ Normally, these microbubbles are absorbed by alveoli and trapped by the pulmonary capillary bed (8-15 $\mu \mathrm{m})$. In HPS, bubbles cannot stay in lung, and they transverse to the lung circulation and enter the left atrium. If microbubbles are seen in left atrium in three to six cardiac cycles after they are seen in right atrium, it is indicative of intrapulmonary shunting; but if it happens within three cardiac cycles, this indicates intracardiac shunting.

Transthoracic echocardiogram (TTE) is not as sensitive as transoesophageal echocardiogram (TEE) because TEE can show bubbles in the pulmonary veins. ${ }^{64,67}$ TEE requires sedation, has more risk because of esophageal varices in cirrhotic patients, and has a higher cost, so it is not usually used in practice. ${ }^{1}$

MAA is a more invasive method that uses the signal of $99 \mathrm{mTc}$-radiolabelled MAA (> $20 \mu \mathrm{m}$ in diameter). In this method, Technetium-99m-labelled albumin is injected, and this larger radionuclide is normally trapped in the pulmonary capillaries. However, in HPS patients with intracardiac or intrapulmonary shunts, these aggregates pass through the pulmonary vasculature and are retained in the brain and kidneys. ${ }^{68}$ Radionuclide uptake to the brain and kidneys is studied in this method, but it is not very sensitive and cannot differentiate between intracardiac and intrapulmonary shunts. ${ }^{17,65}$ Pulmonary angiography is an invasive method, so it is not commonly used in diagnosis of HPS. According to the angiographic patterns and underlying pathophysiology,

Table 1. Diagnostic Criteria of hepatopulmonary syndrome (HPS) (The European Respiratory Society Task Force in 2004) ${ }^{1}$

1- Presence of liver disease and/or portal hypertension

2- Elevated room air alveolar-arterial oxygen gradient $\left[\mathrm{P}(\mathrm{A}-\mathrm{a}) \mathrm{O}_{2}\right.$ gradient $]>15 \mathrm{mmHg}$ or $>20 \mathrm{mmHg}$ when age $\geq 65$ years

3- Evidence of intrapulmonary vascular dilation (IPVD)
HPS can be classified into two types. Type 1 HPS is associated with an increase in the number of visible vessels, and vascular dilatation is more severe in the basal part of lung. Patients with type 1 usually have normal or near normal $\mathrm{PaO}_{2}$ responses to breathing pure oxygen. In contrast, the type 2 pattern of HPS, which is less common, does not respond to $100 \%$ oxygen. ${ }^{69}$ Another method used for embolization when large arteriovenous shunts are suspected is pulmonary angiography. ${ }^{58}$ High-resolution CT can show intrapulmonary vasodilation. Additional methods are used to exclude other pulmonary diseases. Chest radiographs are usually normal, but they sometimes show evidence of severe intrapulmonary vasodilatation. ${ }^{1,58,67,68,70}$

\section{Hypoxemia}

Pulse oximetry is a quick, noninvasive, inexpensive, and useful method to determine arterial oxygenation. ${ }^{71-73}$ It can be used as a screening test for the detection of pulmonary arterial blood oxygenation deficits by measuring the difference between supine and standing oxygen saturation. ${ }^{71-73}$ Nevertheless, oxygenation measured by arterial blood gas (ABG) in the sitting position with room air is the gold standard for diagnosis of HPS. ${ }^{15,71,72,74,75} \mathrm{SaO}_{2}$ is not sufficient to diagnose HPS, ${ }^{72,73}$ so when $\mathrm{SaO}_{2}$ levels are $<97 \%$, an ABG should be considered. ${ }^{75}$ The recommended cutoff value for the diagnosis of HPS is $\mathrm{P}(\mathrm{A}-\mathrm{a}) \mathrm{O}_{2}$ gradient $>15 \mathrm{mmHg}$, and for patients who are older than 64 years, the cutoff is $P(A-a)$ $\mathrm{O}_{2}$ gradient $>20 \mathrm{mmHg} .{ }^{1}$ The European Respiratory Society Task Force in 2004 classified HPS according by stage: mild $\left(\mathrm{PaO}_{2} \geq 80 \mathrm{mmHg}\right)$, moderate $\left(\mathrm{PaO}_{2} 60\right.$ to $\left.<80 \mathrm{mmHg}\right)$, severe $\left(\mathrm{PaO}_{2} 50\right.$ to $\left.<60 \mathrm{mmHg}\right)$, and very severe $\left(\mathrm{PaO}_{2}<\right.$ $50 \mathrm{mmHg}$ ) (Table 2). ${ }^{1}$ Staging is important to determine prognosis and timing of LT. 1,76 Abnormal diffusing capacity of CO can be measured with a lung function test as well. ${ }^{77}$ Biomarkers, such as vascular cell adhesion molecule 1 , intercellular cell adhesion molecule 3, and von Willebrand factor, are new markers to detect HPS, but these markers have not yet been tested in large groups. ${ }^{78,79}$

\section{Prognosis}

There are varying results about prognosis in HPS. It was reported in a multicenter prospective study that a higher overall mortality rate was present in patients with HPS who were candidates for LT. Similar results were found for pre- and post-LT periods, and this mortality was independent of age, sex, race, model end-stage liver disease (MELD) score, the probability of receiving an LT, and hypoxemia. ${ }^{80}$ In an another study, median survival was demonstrated to be 10.6 months, and only $25 \%$ of patients who have $\mathrm{PaO}_{2}<60 \mathrm{mmHg}$ lived for 6 months. ${ }^{81}$ In a different study that compared survival rates in HPS and non-HPS patients who had similar liver function, it was shown that median survival was 24 months

Table 2. Staging of HPS (The European Respiratory Society Task Force in 2004) ${ }^{1}$

\begin{tabular}{ll}
\hline Mild & $\mathrm{PaO}_{2} \geq 80 \mathrm{~mm} \mathrm{Hg}$ \\
Moderate & $\mathrm{PaO}_{2} 60-79 \mathrm{~mm} \mathrm{Hg}$ \\
Severe & $\mathrm{PaO}_{2} 50-59 \mathrm{~mm} \mathrm{Hg}$ \\
Very severe & $\mathrm{PaO}_{2}<50 \mathrm{~mm} \mathrm{Hg}$ \\
\hline
\end{tabular}


(5-year survival of $23 \%$ ) in HPS group and 87 months (5-year survival of $63 \%$ ) in non-HPS group. ${ }^{57}$ The level of oxygenation reflecting the severity of HPS was not correlated with severity of liver disease, which was determined by ChildPugh or MELD score. ${ }^{57,63,82}$ However, there are newer studies that have shown no reduction in survival in patients with HPS who are on the LT waiting list. ${ }^{83}$

\section{Treatment}

The only known effective therapy for HPS is $\mathrm{LT}^{82,84-89}$ with an improvement in oxygenation at 1 year. ${ }^{85-87}$ After LT in HPS patients, the 5-year survival rate was shown to be approximately $76 \%$, which is similar to patients with non-HPS. ${ }^{57}$ In Swanson et al., $80 \%$ of all HPS patients showed complete resolution after $\mathrm{LT}^{57}$ and the mortality rate was $16 \%$ in the whole group, $30 \%$ in the severe HPS group at 3 months. ${ }^{57}$ Some studies showed worse survival in patients who have $\mathrm{PaO}_{2} \leq 50 \mathrm{mmHg}$ alone or with MAA shunt fraction $\geq 20 \% .{ }^{84,88}$ However, some other studies showed that there were no significant differences in survival between any HPS and non-HPS patients. ${ }^{86,89}$ Iyer et al. reported that there was no association between $\mathrm{PaO}_{2}$ levels at diagnosis and survival rates after transplantation. ${ }^{85}$ Post-transplantation early death predictors are pretransplantation $\mathrm{PaO}_{2} \leq 50 \mathrm{mmHg}$ and a lung scan with brain uptake of $20 \%$ or more. ${ }^{84}$ Patients with advanced HPS $\left(\mathrm{PaO}_{2}<60 \mathrm{mmHg}\right)$ are eligible for MELD exception points to increase priority for transplantation. In a recent study, US MELD-era data were analyzed, and it was found that the present system of allocating HPS MELD exception points provides a survival advantage to wait listed patients with HPS compared to patients without HPS exception. ${ }^{90,91}$ In the same study, patients with a pretransplantation $\mathrm{PaO}_{2}<44 \mathrm{mmHg}$ had significantly lower posttransplantation survival rates compared with those with a $\mathrm{PaO}_{2}$ between 44 and $54 \mathrm{mmHg}{ }^{90}$ It may come to mind that living donor LT (LDLT) may be more suitable than deceased donor LT (DDLT) because of the advantages of immediate availability of graft and opportunity to stabilize patient before LT. ${ }^{86}$ However, some reports have shown that complication rates are the same between LDLT and DDLT patients. ${ }^{92-95}$ To improve survival after LT, patients who are on the waiting list should be screened properly, and adequate oxygen should be given. ${ }^{89}$ It should be remembered that HPS patients who are not candidates for LT may be candidates for localized resection or coil embolization of the dilated pulmonary vessels as a palliative treatment. ${ }^{70}$ This is especially true for patients with type 2 lesions who would not respond to LT. ${ }^{96}$

\section{Medical therapy}

Since the main disease mechanism involves vasodilation and angiogenesis mediated by $\mathrm{NO}$ and $\mathrm{CO}$, treatment studies have targeted this pathway but with disappointing results. Some of the agents used in these studies are methylene blue, N(G)nitro-L-arginine methyl ester (L-NAME), curcumin, terlipressin, somatostatin analogues, NOS inhibitors, cyclooxygenase inhibitors, antibiotics, chemotherapeutics, glucocorticoids, and beta blockers. 1,36,76

Pentoxifylline (PTX) is a nonspecific phosphodiesterase inhibitor that also inhibits TNF- $\alpha,{ }^{97}$ monocyte chemoattractant protein-1 (MCP-1), macrophage inhibitory protein-1 (MIP-1), interleukin-6, and interleukin-8 and decreases the expression of adhesion molecules and activation and proliferation of neutrophils. ${ }^{98-101}$ It is used in HPS patients because of its inhibitory effect on iNOS, leading to a subsequent decrease in NO production and downregulation of angiogenesis. ${ }^{102} \mathrm{~A}$ few studies have shown that improving oxygenation prevents development of HPS in both animal models and humans. ${ }^{51,103}$ However, in a different study, Tanikella et al. administered a lower dose of PTX (400 mg once daily by mouth for 7 days, followed by 400 mg twice daily for 7 days, and then $400 \mathrm{mg}$ thrice daily for 42 days) because of side effects and did not find any improvement after PTX therapy in cirrhotic patients with HPS. TNF- $\alpha$ levels were not decreased significantly before and after treatment with PTX. ${ }^{104}$ To date, there have been no randomized, placebo, controlled trials regarding the use of PTX in patients with HPS.

Garlic (Allium sativum) is thought to decrease NO synthesis, and although it has the potential to be a therapy for HPS, it has also been reported to cause an increase in NO synthesis. ${ }^{105}$ There are a few studies showing improvement in oxygen levels with garlic therapy. ${ }^{106,107}$

Methylene blue (MB) is an oxidizing agent and has a vasoconstrictor effect by blocking the stimulation of soluble guanylate cyclase by NO. ${ }^{36,38}$ Although some have found favorable results, ${ }^{36,38}$ no randomized, placebo-controlled trials has been performed on the use of MB in HPS patients. ${ }^{108}$

Norfloxacin is an active quinolone antibiotic against gram negative bacteria. Norfloxacin decreases pulmonary intravascular macrophage accumulation and reduces HPS by decreasing bacterial translocation. ${ }^{109}$ It is used for its potential to prevent bacterial translocation in cirrhosis patients. ${ }^{110}$ There is a case report that showed improvement in HPS after administration of $400 \mathrm{mg}$ oral norfloxacin two times per day. ${ }^{111}$ Gupta et al. showed that there was no major effect of norfloxacin on gas exchange in patients with hepatopulmonary syndrome. ${ }^{112}$ However, there should be more randomized studies to discuss the effect of norfloxacin in improvement of HPS.

Transjugular intrahepatic portosystemic shunt (TIPS) placement is a medical intervention that has been associated with improvement of HPS in several case reports, ${ }^{113-114}$ but there is also a risk that TIPS may worsen HPS by increasing the hyperkinetic state, leading to more pulmonary vasodilatation, shunting, and hypoxemia. The American Association for the Study of Liver Disease guidelines do not recommend TIPS placement for the treatment of HPS. ${ }^{115}$

\section{Conclusion}

HPS is a severe pulmonary vascular complication of liver disease. As it is usually asymptomatic, all patients should be screened for its presence prior to LT since it can affect survival after LT. There is no medical therapy described to date, and LT is considered to be the only effective therapy. Complete resolution of HPS after LT is usually seen within a year in most HPS patients. The correlation between pre-LT $\mathrm{PaO}_{2}$ levels and the long term post-LT survival of patients with HPS needs to be studied further.

\section{Conflict of interest}

None

\section{Author contributions}

Writing the article (CC, AMC, MG, NND, AG). 


\section{References}

[1] Rodriguez-Roisin R, Krowka MJ, Herve P, Fallon MB. Pulmonary-hepatic vascular Disorders (PHD). Eur Respir J 2004;24:861-880. doi: 10.1183/09031936. 04.00010904.

[2] Rodriguez-Roisin R, Agusti AG, Roca J. The hepatopulmonary syndrome: newname, old complexities. Thorax 1992;47:897-902. doi: 10.1136/thx. 47.11.897.

[3] De BK, Sen S, Sanyal R. Hepatopulmonary syndrome in non-cirrhotic portal hypertension. Ann Intern Med 2000;132:924. doi: 10.7326/0003-4819132-11-200006060-00023.

[4] Regev A, Yeshurun M, Rodriguez M, Sagie A, Neff GW, Molina EG, et al. Transient hepatopulmonary syndrome in a patient with acute hepatitis $A$. J Viral Hepat 2001;8:83-86. doi: 10.1046/j.1365-2893.2001.00270.x

[5] Teuber G, Teupe C, Dietrich CF, Caspary WF, Buhl R, Zeuzem S. Pulmonary dysfunction in non-cirrhotic patients with chronic viral hepatitis. Eur J Intern Med 2002;13:311-318. doi: 10.1016/S0953-6205(02)00066-3.

[6] Fuhrmann V, Madl C, Mueller C, Holzinger U, Kitzberger R, Funk GC, et al. Hepatopulmonary syndrome in patients with hypoxic hepatitis. Gastroenterology 2006;131:69-75 doi: 10.1053/j.gastro.2006.04.014.

[7] De BK, Sen S, Biswas PK, Sanyal R, Majumdar D, Biswas J. Hepatopulmonary syndrome in inferior vena cava obstruction responding to cavoplasty. Gastroenterology 2000;118:192-196. doi: 10.1016/S0016-5085(00)70428-8.

[8] Tercier S, Delarue A, Rouault F, Roman C, Breaud J, Petit P. Congenital portocaval fistula associated with hepatopulmonary syndrome: ligation vs liver transplantation. J Pediatr Surg 2006;41:e1-e3. doi: 10.1016/j.jpedsurg. 2005.10.071.

[9] Ioachimescu OC, Mehta AC, Stoller JK. Hepatopulmonary syndrome following portopulmonary hypertension. Eur Respir ] 2007;29:1277-1280. doi: 10.1183/09031936.00140306.

[10] Zopey R, Susanto I, Barjaktarevic I, Wang T. Transition from hepatopul-monary syndrome to portopulmonary hypertension: A case series of 3 patients. Case Rep Pulmonol 2013;2013:561870. doi: 10.1155/2013/561870.

[11] Shao D, Park JE, Wort SJ. The role of endothelin-1 in the pathogenesis of pulmonary arterial hypertension. Pharmacol Res 2011;63:504-511. doi: 10.1016/j.phrs.2011.03.003.

[12] Stoller JK, Lange PA, Westveer MK, Carey WD, Vogt D, Henderson JM. Prevalence and reversibility of the hepatopulmonary syndrome after liver transplantation. The Cleveland Clinic experience. West J Med 1995;163: 133-138.

[13] Hopkins WE, Waggoner AD, Barzilai B. Frequency and significance of intrapulmonary right-to-left shunting in end-stage hepatic disease. Am J Cardiol 1992;70:516-519. doi: 10.1016/0002-9149(92)91200-N.

[14] Krowka MJ, Cortese DA. Hepatopulmonary syndrome. Current concepts in diagnostic and therapeutic considerations. Chest 1994;105:1528. doi: 10. 1378/chest.105.5.1528.

[15] Arguedas MR, Singh H, Faulk DK, Fallon MB. Utility of pulse oximetry screening for hepatopulmonary syndrome. Clin Gastroenterol Hepatol 2007; 5:749-754. doi: 10.1016/j.cgh.2006.12.003.

[16] Kim BJ, Lee SC, Park SW, Choi MS, Koh KC, Paik SW, et al. Characteristics and prevalence of intrapulmonary shunt detected by contrast echocardiography with harmonic imaging in liver transplant candidates. Am J Cardiol 2004:94:525-528. doi: 10.1016/j.amjcard.2004.04.074.

[17] Abrams GA, Jaffe CC, Hoffer PB, Binder HJ, Fallon MB. Diagnostic utility of contrast echocardiography and lung perfusion scan in patients with hepatopulmonary syndrome. Gastroenterology 1995;109:1283-1288. doi: 10 . 1016/0016-5085(95)90589-8.

[18] Martinez GP, Barbera JA, Visa J, Rimola A, Paré JC, Roca J, et al. Hepatopulmonary syndrome in candidates for liver transplantation. J Hepatol 2001;34:651-657. doi: 10.1016/S0168-8278(00)00108-2.

[19] Schenk P, Fuhrmann V, Madl C, Funk G, Lehr S, Kandel O, et al. Hepatopulmonary syndrome: prevalence and predictive value of various cut offs for arterial oxygenation and their clinical consequences. Gut 2002;51:853859. doi: 10.1136/gut.51.6.853.

[20] Katsuta $Y$, Honma $H$, Zhang $X J$, Ohsuga $M$, Komeichi $H$, Shimizu $S$, et al. Pulmonary blood transit time and impaired arterial oxygenation in patients with chronic liver disease. J Gastroenterol 2005;40:57-63. doi: 10.1007/ s00535-004-1495-6.

[21] Castaing $Y$, Manier G. Hemodynamic disturbances and VA/Q matching in hypoxemic cirrhotic patients. Chest 1989;96:1064-1069. doi: 10 . 1378/chest.96.5.1064.

[22] Yang W, Zhang J, Hu B, Wei W, Julie V, Gianfranco A, et al. The role of receptor tyrosine kinase activation in cholangiocytes and pulmonary vascular endothelium in experimental hepatopulmonary syndrome. Am J Physiol Gastrointest Liver Physiol 2014;306:G72-80. doi: 10.1152/ajpgi.00178.2013.

[23] Fallon MB, Abrams GA, Luo B, Hou Z, Dai J, Ku DD. The role of endothelial nitric oxide synthase in the pathogenesis of a rat model of hepatopulmonary syndrome. Gastroenterology 1997;113:606-614. doi: 10.1053/gast.1997. v113.pm9247483.
[24] Fallon MB, Abrams GA, McGrath JW, Hou Z, Luo B. Common bile duct ligation in the rat: a model of intrapulmonary vasodilatation and hepatopulmonary syndrome. Am J Phys 1997;272:G779-784.

[25] Zhang J, Ling Y, Luo B, Tang L, Stockard C, Grizzle WE, et al. Analysis of pulmonary heme oxygenase- 1 and nitric oxide synthase alterations in experimental hepatopulmonary syndrome. Gastroenterology 2003;125: 1441-1451. doi: 10.1016/j.gastro.2003.07.005.

[26] Zhang M, Luo B, Chen S], Abrams GA, Fallon MB. Endothelin-1 stimulation of endothelial nitric oxide synthase in the pathogenesis of hepatopulmonary syndrome. Am J Phys 1999;277:G944-952.

[27] Zhang $X$ J, Katsuta $Y$, Akimoto $T$, Ohsuga $M$, Aramaki T, Takano $T$. Intrapulmonary vascular dilatation and nitric oxide in hypoxemic rats with chronic bile duct ligation. J Hepatol 2003;39:724-730. doi: 10.1016/S0168-8278 (03)00430-6.

[28] Luo B, Liu L, Tang L, Zhang J, Ling Y, Fallon MB. ET-1 and TNF-alpha in HPS: analysis in pre hepatic portal hypertension and biliary and nonbiliary cirrhosis in rats. Am J Physiol Gastrointest Liver Physiol 2004;286:G294-303. doi: 10.1152/ajpgi.00298.2003.

[29] Luo B, Liu L, Tang L, Zhang J, Stockard C, Grizzle W, et al. Increased pulmonary vascular endothelin $B$ receptor expression and responsiveness to endothelin-1 in cirrhotic and portal hypertensive rats: a potential mechanism in experimental hepatopulmonary syndrome. J Hepatol 2003;38: 556-563. doi: 10.1016/S0168-8278(03)00012-6.

[30] Luo B, Tang L, Wang Z, Zhang J, Ling Y, Feng W, et al. Cholangiocyte endothelin 1 and transforming growth factor beta1 production in rat experimental hepatopulmonary syndrome. Gastroenterology 2005;129:682-695. doi: $10.1016 / j$.gastro.2005.05.050.

[31] Ling Y, Zhang J, Luo B, Song D, Liu L, Tang L, et al. The role of endothelin-1 and the endothelin $B$ receptor in the pathogenesis of hepatopulmonary syndrome in the rat. Hepatology 2004;39:1593-1602. doi: 10.1002/hep.20244.

[32] Zhang J1, Ling Y, Tang L, Luo B, Pollock DM, Fallon MB Attenuation of experimental hepatopulmonary syndrome in endothelin $B$ receptor-deficient rats. Am J Physiol Gastrointest Liver Physiol 2009;296:G704-708. doi: 10.1152/ ajpgi.90627.2008

[33] Schroeder RA, Ewing CA, Sitzmann JV, Kuo PC. Pulmonary expression of iNOS and $\mathrm{HO}-1$ protein is upregulated in a rat model of prehepatic portal hypertension. Dig Dis Sci 2000;45:2405-2410. doi: 10.1023/A: 1005651327654.

[34] Rolla G, Brussino L, Colagrande P, Dutto L, Polizzi S, Scappaticci E, et al. Exhaled nitric oxide and oxygenation abnormalities in hepatic cirrhosis. Hepatology 1997;26:842-847. doi: 10.1002/hep.510260406.

[35] Rolla G, Brussino L, Colagrande P, Scappaticci E, Morello M, Bergerone S, et al. Exhaled nitric oxide and impaired oxygenation in cirrhotic patients before and after liver transplantation. Ann Intern Med 1998;129:375-378. doi: 10.7326/0003-4819-129-5-199809010-00005.

[36] Schenk P, Madl C, Rezaie-Majd S, Lehr S, Muller C. Methylene blue improves the hepatopulmonary syndrome. Ann Intern Med 2000;133:701-706. doi: 10.7326/0003-4819-133-9-200011070-00012.

[37] Fallon MB. Methylene blue and cirrhosis: pathophysiologic insights, therapeutic dilemmas. Ann Intern Med 2000;133:738-740. doi: 10.7326/00034819-133-9-200011070-00016.

[38] Miyamoto A, Katsuta Y, Zhang XJ, Li HL, Ohsuga M, Komeichi H, et al. Effect of chronic methylene blue administration on hypoxemia in rats with common bile duct ligation. Hepatol Res 2010;40:622-632. doi: 10. 1111/j.1872-034X.2010.00640.x.

[39] Arguedas MR, Drake BB, Kapoor A, Fallon MB. Carboxyhemoglobin levels in cirrhotic patients with and without hepatopulmonary syndrome. Gastroenterology 2005;128:328-333. doi: 10.1053/j.gastro.2004.11.061.

[40] Carter EP, Hartsfield CL, Miyazono M, Jakkula M, Morris KG Jr, McMurtry IF, et al. Regulation of heme oxygenase-1 by nitric oxide during hepatopulmonary syndrome. Am J Physiol Lung Cell Mol Physiol 2002;283:L346-L353. doi: 10.1152/ajplung.00385.2001.

[41] Guo SB, Duan ZJ, Li Q, Sun XY. Effects of heme oxygenase-1 on pulmonary function and structure in rats with liver cirrhosis. Chin Med J (Engl) 2011; 124:918-922.

[42] Zhang HY, Han DW, Su AR, Zhang LT, Zhao ZF, Ji JQ, et al. Intestinal endotoxemia plays a central role in development of hepatopulmonary syndrome in a cirrhotic rat model induced by multiple pathogenic factors. World J Gastroenterol 2007;13:6385-6395. doi: 10.3748/wjg.v13.i47.6385.

[43] Zhang HY, Han DW, Wang XG, Zhao YC, Zhou X, Zhao HZ. Experimental study on the role of endotoxin in the development of hepatopulmonary syndrome. World J Gastroenterol 2005;11:567-572. doi: 10.3748/wjg.v11.i4.567.

[44] Sztrymf B, Libert JM, Mougeot C, Lebrec D, Mazmanian M, Humbert M, et al. Cirrhotic rats with bacterial translocation have higher incidence and severity of hepatopulmonary syndrome. J Gastroenterol Hepatol 2005;20:15381544. doi: $10.1111 / j .1440-1746.2005 .03914$ x

[45] Nunes H, Lebrec D, Mazmanian M, Capron F, Heller J, Tazi KA, et al. Role of nitric oxide in hepatopulmonary syndrome in cirrhotic rats. Am J Respir Crit Care Med 2001;164:879-885. doi: 10.1164/ajrccm.164.5.2009008. 
[46] Liu L, Liu N, Zhao $Z$, Liu J, Feng $Y$, Jiang $H$, et al. TNF-alpha neutralization improves experimental hepatopulmonary syndrome in rats. Liver Int 2012; 32:1018-1026. doi: 10.1111/j.1478-3231.2012.02821.x.

[47] Sztrymf B, Rabiller A, Nunes H, Savale L, Lebrec D, A. Le Pape, et al. Prevention of hepatopulmonary syndrome and hyperdynamic state by pentoxifylline in cirrhotic rats. Eur Respir ] 2004;23:752-758. doi: 10.1183/ 09031936.04 .00080404$.

[48] Gomez FP, Barbera JA, Roca J, Burgos F, Gistau C, Rodríguez-Roisinez R. Effects of nebulized $\mathrm{N}(\mathrm{G})$-nitro-L-arginine methyl ester in patients with hepatopulmonary syndrome. Hepatology 2006;43:1084-1091. doi: 10.1002/hep. 21141.

[49] Bosch J. Vascular deterioration in cirrhosis: the big picture. J Clin Gastroenterol 2007;41:S247-253. doi: 10.1097/MCG.0b013e3181572357.

[50] Thenappan T, Goel A, Marsboom G, Fang YH, Toth PT, Zhang HJ, et al. A central role for $C D 68(+)$ macrophages in hepatopulmonary syndrome. Reversal by macrophage depletion. Am J Respir Crit Care Med 2011;183: 1080-1091. doi: 10.1164/rccm.201008-13030C.

[51] Zhang J, Luo B, Tang L, Wang Y, Stockard CR, Kadish I, et al. Pulmonary angiogenesis in a rat model of hepatopulmonary syndrome. Gastroenterology 2009;136:1070-1080. doi: 10.1053/j.gastro.2008.12.001.

[52] Zhang J, Ling $Y$, Tang L, Luo B, Chacko BK, Patel RP, et al. Pentoxifylline attenuation of experimental hepatopulmonary syndrome. J Appl Physiol (1985) 2007;102:949-955. doi: 10.1152/japplphysiol.01048.2006.

[53] Zhang J, Yang W, Luo B, Hu B, Maheshwari A, Fallon M B. The role of CX(3) $\mathrm{CL1} / \mathrm{CX}(3) \mathrm{CR} 1$ in pulmonary angiogenesis and intravascular monocyte accumulation in rat experimental hepatopulmonary syndrome. J Hepatol 2012;57:752-758. doi: 10.1016/j.jhep.2012.05.014.

[54] Zhang J, Yang W, Hu B, Wu W, Fallon MB. Endothelin-1 activation of the endothelin $B$ receptor modulates pulmonary endothelial CX3CL1 and contributes to pulmonary angiogenesis in experimental hepatopulmonary syndrome. Am J Pathol 2014;184:1706-1714. doi: 10.1016/j.ajpath.2014.02.027.

[55] Chang CC, Chuang CL, Lee FY, Wang SS, Lin HC, Huang HC, et al. Sorafenib treatment improves hepatopulmonary syndrome in rats with biliary cirrhosis. Clin Sci (Lond) 2013;124:457-466. doi: 10.1042/CS20120052.

[56] Anand AC, Mukherjee D, Rao KS, Seth AK. Hepatopulmonary syndrome: prevalence and clinical profile. Indian J Gastroenterol 2001;20:24-27.

[57] Swanson KL, Wiesner RH, Krowka MJ. Natural history of hepatopulmonary syndrome: impact of liver transplantation. Hepatology 2005;41:11221129. doi: 10.1002/hep.20658.

[58] Singh C, Sager JS. Pulmonary complications of cirrhosis. Med Clin North Am 2009;93:871-883, viii. doi: 10.1016/j.mcna.2009.03.006.

[59] Mohammad AA, Fatemi SR, Mirzaee V, Khoshbaten M, Talebipour B, Sharifi A, et al. Clinical features of hepatopulmonary syndrome in cirrhotic patients. World J Gastroenterol 2006;12:1954-1956.

[60] Gomez FP, Martinez-Palli G, Barbera JA, Roca J, Navasa M, Rodríguez-Roisin R. Gas exchange mechanism of orthodeoxia in hepatopulmonary syndrome. Hepatology 2004;40:660-666. doi: 10.1002/hep.20358.

[61] Silverio AO, Guimaraes DC, Elias LF, Milanez EO, Naves S. Are the spider angiomas skin markers of hepatopulmonary syndrome? Arq Gastroenterol 2013;50:175-179. doi: 10.1590/S0004-28032013000200031.

[62] Palma DT, Philips GM, Arguedas MR, Harding SM, Fallon MB. Oxygen desaturation during sleep in hepatopulmonary syndrome. Hepatology 2008;47: 1257-1263. doi: 10.1002/hep.22143.

[63] Krowka MJ, Wiseman GA, Burnett OL, Spivey JR, Therneau S, Poraykoet MK, et al. Hepatopulmonary syndrome: a prospective study of relationships between severity of liver disease, $\mathrm{Pa}, \mathrm{O} 2$ response to $100 \%$ oxygen, and brain uptake after 99 mTc MAA lung scanning. Chest 2000;118:615-624. doi: 10.1378/chest.118.3.615.

[64] Rollan MJ, Munoz AC, Perez T, Bratos JL. Value of contrast echocardiography for the diagnosis of hepatopulmonary syndrome. Eur J Echocardiogr 2007; 8:408-410. doi: 10.1016/j.euje.2006.07.005.

[65] Mimidis KP, Vassilakos PI, Mastorakou AN, Spiropoulos KV, LambropoulouKaratza CA, Thomopoulos KC, et al. Evaluation of contrast echocardiography and lung perfusion scan in detecting intrapulmonary vascular dilatation in normoxemic patients with early liver cirrhosis. Hepatogastroenterology 1998;45:2303-2307.

[66] Aller R, Moya JL, Moreira V, Garcia-Lledo A, Sanromán AL, Paino C, et al. Diagnosis and grading of intrapulmonary vascular dilatation in cirrhotic patients with contrast transesophageal echocardiography. J Hepatol 1999; 31:1044-1052. doi: 10.1016/S0168-8278(99)80317-1.

[67] Aller R, Moya JL, Moreira V, Boixeda D, Cano A, Picher J, et al. Diagnosis of hepatopulmonary syndrome with contrast transesophageal echocardiography: advantages over contrast transthoracic echocardiography. Dig Dis Sci 1999; 44:1243-1248. doi: 10.1023/A:1026657114256.

[68] Wolfe JD, Tashkin DP, Holly FE, Brachman MB, Genovesi MG. Hypoxemia of cirrhosis: detection of abnormal small pulmonary vascular channels by a quantitative radionuclide method. Am J Med 1977;63:746-754. doi: 10.1016/ 0002-9343(77)90161-9.
[69] Krowka MJ, Dickson ER, Cortese DA. Hepatopulmonary syndrome. Clinical observations and lack of therapeutic response to somatostatin analogue. Chest 1993;104:515-521. doi: 10.1378/chest.104.2.515.

[70] Herve P, Le Pavec J, Sztrymf B, Decante B, Savale L, Stibon O. Pulmonary vascular abnormalities in cirrhosis. Best Pract Res Clin Gastroenterol 2007; 21:141-159. doi: 10.1016/j.bpg.2006.07.011.

[71] Deibert P, Allgaier HP, Loesch S, Muller C, Olschewski M, Hamm H, et al. Hepatopulmonary syndrome in patients with chronic liver disease: role of pulse oximetry. BMC Gastroenterol 2006;6:15. doi: 10.1186/1471-230X6-15.

[72] Voiosu A, Voiosu T, Stanescu CM, Chirila L, Băicuş C, Voiosu R. Novel predictors of intrapulmonary vascular dilatations in cirrhosis: extending the role of pulse oximetry and echocardiography. Acta Gastroenterol Belg 2013;76:241-245.

[73] Hoerning A, Raub S, Neudorf U, Muntjes C, Kathemann S, Lainka E, et al. Pulse oximetry is insufficient for timely diagnosis of hepatopulmonary syndrome in children with liver cirrhosis. J Pediatr 2014;164:546-552. doi: 10. 1016/j.jpeds.2013.10.070.

[74] Abrams GA, Sanders MK, Fallon MB. Utility of pulse oximetry in the detection of arterial hypoxemia in liver transplant candidates. Liver Transpl 2002; 8:391-396. doi: 10.1053/jlts.2002.32252.

[75] Kochar R, Tanikella R, Fallon MB. Serial pulse oximetry in hepatopulmonary syndrome. Dig Dis Sci 2011;56:1862-1868. doi: 10.1007/s10620-0111600-7.

[76] Rodriguez-Roisin R, Krowka MJ. Hepatopulmonary syndrome - a liverinduced lung vascular disorder. N Engl J Med 2008;358:2378-2387. doi: 10.1056/NEJMra0707185.

[77] Martinez GP, Barbera JA, Visa J, Rimola A, Paré JC, Roca J, et al. Hepatopulmonary syndrome in candidates for liver transplantation. J Hepatol 2001; 34:651-657. doi: 10.1016/S0168-8278(00)00108-2.

[78] Zamirian M, Aslani A, Shahrzad S. Left atrial volume: a novel predictor of hepatopulmonary syndrome. Am J Gastroenterol 2007;102:1392-1396. doi: 10.1111/j.1572-0241.2007.01228.x.

[79] Horvatits T, Drolz A, Roedl K, Herkner H, Ferlitsch A, Perkmann T, et al. Von Willebrand factor antigen for detection of hepatopulmonary syndrome in patients with cirrhosis. J Hepatol 2014;61:544-549. doi: 10.1016/j.jhep. 2014.04.025.

[80] Fallon MB, Krowka MJ, Brown RS, Trotter JF, Zacks S, Roberts KE, et al. Impact of hepatopulmonary syndrome on quality of life and survival in liver transplant candidates. Gastroenterology 2008;135:1168-1175. doi: 10.1053/j.gastro.2008.06.038.

[81] Schenk P, Schöniger-Hekele M, Fuhrmann V, Madl C, Silberhumer G, Müller C. Prognostic significance of the hepatopulmonary syndrome in patients with cirrhosis. Gastroenterology 2003;125:1042-1052. doi: 10.1016/ S0016-5085(03)01207-1.

[82] Gupta S, Castel H, Rao RV, Picard M, Lilly L, Faughnan ME, et al. Improved survival after liver transplantation in patients with hepatopulmonary syndrome. Am J Transplant 2010;10:354-363. doi: 10.1111/j.1600-6143. 2009.02822.x.

[83] Pascasio JM, Grilo I, López-Pardo FJ, Ortega-Ruiz F, Tirado JL, Sousa JM, et al. Prevalence and severity of hepatopulmonary syndrome and its influence on survival in cirrhotic patients evaluated for liver transplantation. Am J Transplant 2014;14:1391-1399. doi: 10.1111/ajt.12713.

[84] Arguedas MR, Abrams GA, Krowka MJ, Fallon MB. Prospective evaluation of outcomes and predictors of mortality in patients with hepatopulmonary syndrome undergoing liver transplantation. Hepatology 2003;37:192-197. doi: $10.1053 /$ jhep.2003.50023.

[85] Iyer VN, Swanson KL, Cartin-Ceba R, Dierkhising RA, Rosen CB, Heimbach JK, et al. Hepatopulmonary syndrome: favorable outcomes in the MELD exception era. Hepatology 2013;57:2427-2435. doi: 10.1002/hep.26070.

[86] Saigal S, Choudhary N, Saraf N, Kotecha H, Kakodkar R, Mohanka R, et al. Excellent outcome of living donor liver transplantation in patients with hepatopulmonary syndrome: a single centre experience. Clin Transplant 2013;27:530-534. doi: 10.1111/ctr.12126.

[87] Kim HY, Choi MS, Lee SC, Park SW, Lee JH, Koh KC, et al. Outcomes in patients with hepatopulmonary syndrome undergoing liver transplantation. Transplant Proc 2004;36:2762-2763. doi: 10.1016/j.transproceed.2004. 10.002.

[88] Schiffer E, Majno $P$, Mentha G, Giostra E, Burri H, Klopfenstein CE, et al. Hepatopulmonary syndrome increases the postoperative mortality rate following liver transplantation: a prospective study in 90 patients. Am J Transplant 2006;6:1430-1437. doi: 10.1111/j.1600-6143.2006.01334.x.

[89] Deberaldini M, Arcanjo AB, Melo E, Da SR, Felício HC, Arroyo PC, et al. Hepatopulmonary syndrome: morbidity and survival after liver transplantation. Transplant Proc 2008;40:3512-3516. doi: 10.1016/j.transproceed 2008.08.134.

[90] Goldberg DS, Krok K, Batra S, Trotter JF, Kawut SM, Fallon MB. Impact of the hepatopulmonary syndrome MELD exception policy on outcomes of patients after liver transplantation: an analysis of the UNOS database. Gastroenterology 2014;146:1256-1265. doi: 10.1053/j.gastro.2014.01.005. 
[91] Sulieman BM, Hunsicker LG, Katz DA, Voigt MD. OPTN policy regarding prioritization of patients with hepatopulmonary syndrome: does it provide equitable organ allocation? Am J Transplant 2008;8:954-964. doi: 10. $1111 / j .1600-6143.2007 .02124 . x$

[92] Carey EJ, Douglas DD, Balan V, Vargas HE, Byrne TJ, Moss AA, et al. Hepatopulmonary syndrome after living donor liver transplantation and deceased donor liver transplantation: a single-center experience. Liver Transpl 2004;10:529-533. doi: 10.1002/It.20127.

[93] Chen K, Li B. Reversal of severe hepatopulmonary syndrome in chronic hepatic cirrhosis by living donor liver transplantation: report of two cases. Surg Today 2011;41:441-443. doi: 10.1007/s00595-009-4219-y.

[94] Urahashi T, Mizuta K, Sanada Y, Umehara M, Wakiya T, Hishikawa S, et al. Pediatric living donor liver transplantation for biliary atresia with hepatopulmonary syndrome: the gift of a second wind. Pediatr Surg Int 2011;27: 817-821. doi: 10.1007/s00383-011-2866-8.

[95] Motomura T, Ikegami T, Mano Y, Nagata S, Sugimachi K, Gion T, et al. Living donor liver transplantation for end-stage liver disease with severe hepatopulmonary syndrome: report of a case. Surg Today 2011;41:436-440. doi: 10.1007/s00595-009-4260-x

[96] Aladagi M, Gürakar A, Nizami I, Dahr AS, Wright H, Sebastian A, et al. Peri and postoperative pulmonary complications among cirrhotic individuals. Turk J Gastroenterol 2004;15:207-212.

[97] Zabel P, Schade F U, Schlaak M. Inhibition of endogenous TNF formation by pentoxifylline. Immunobiology 1993;187:447-443. doi: 10.1016/S01712985(11)80356-6.

[98] Chen YM, Lin SN, Chiang WC, Wu KD, Tsai TJ. Pentoxifylline ameliorates proteinuria through suppression of renal monocyte chemoattractant protein-1 in patients with proteinuric primary glomerular diseases. Kidney Int 2006;69:1410-1415. doi: 10.1038/sj.ki.5000302.

[99] Poulakis N, Androutsos G, Kazi D, Bastas A, Provata A, Bitsakou C, et al. The differential effect of pentoxifylline on cytokine production by alveolar macrophages and its clinical implications. Respir Med 1999;93:52-57. doi: 10.1016/S0954-6111(99)90077-X.

[100] Neuner P, Klosner G, Pourmojib M, Knobler R, Schwarz T. Pentoxifylline in vivo and in vitro down-regulates the expression of the intercellular adhesion molecule-1 in monocytes. Immunology 1997;90:435-439. doi: 10. 1111/j.1365-2567.1997.00435.x.

[101] Toda K, Kumagai N, Kaneko F, Tsunematsu S, Tsuchimotoet K, Saito H, et al. Pentoxifylline prevents pig serum-induced rat liver fibrosis by inhibiting interleukin-6 production. J Gastroenterol Hepatol 2009;24:860-865. doi: 10.1111/j.1440-1746.2008.05749.x.

[102] Trajković V1, Badovinac V, Popadić D, Hadzić O, Stojković MM. Cell-specific effects of pentoxifylline on nitric oxide production and inducible nitric oxide synthase mRNA expression. Immunology 1997;92:402-406. doi: 10. 1046/j.1365-2567.1997.00354.x.
[103] Gupta LB, Kumar A, Jaiswal AK, Yusuf J, Mehta V, Tyagi S, et al. Pentoxifylline therapy for hepatopulmonary syndrome: a pilot study. Arch Intern Med 2008;168:1820-1823. doi: 10.1001/archinte.168.16.1820.

[104] Tanikella R, Philips GM, Faulk DK, Kawut SM. Fallon M B. Pilot study of pentoxifylline in hepatopulmonary syndrome. Liver Transpl 2008;14: 1199-1203. doi: 10.1002/lt.21482.

[105] Nagae S, Ushijima M, Hatono S, Imai1 J, Kasuga1 S, Matsuura $\mathrm{H}$, et al. Pharmacokinetics of the garlic compound S-allylcysteine. Planta Med 1994;60:214-217. doi: 10.1055/s-2006-959461.

[106] Abrams GA, Fallon MB. Treatment of hepatopulmonary syndrome with Allium sativum L. (Garlic): a pilot trial. J Clin Gastroenterol 1998;27:232235. doi: 10.1097/00004836-199810000-00010.

[107] De BK, Dutta D, Pal SK, Gangopadhyay S, Das Baksi S, Pani A. The role of garlic in hepatopulmonary syndrome: a randomized controlled trial. Can J Gastroenterol 2010;24:183-188.

[108] Eshraghian A, Kamyab AA, Yoon SK. Pharmacological Treatment for Hepatopulmonary Syndrome. Biomed Res Int 2013;2013:670139. doi: 10. $1155 / 2013 / 670139$.

[109] Rabiller A, Nunes H, Lebrec D, Tazi KA, Wartski M, Dulmet E, et al. Prevention of gram negative translocation reduces the severity of hepatopulmonary syndrome. Am J Respir Crit Care Med 2002;166:514-517. doi: 10. 1164/rccm.200201-0270C.

[110] Gines P, Rimola A, Planas R, Vargas V, Marco F, Almela M, et al. Norfloxacin prevents spontaneous bacterial peritonitis recurrence in cirrhosis: results of a double-blind, placebo-controlled trial. Hepatology 1990;12:716-724. doi: $10.1002 /$ hep.1840120416.

[111] Anel RM, Sheagren JN. Novel presentation and approach to management of hepatopulmonary syndrome with use of antimicrobial agents. Clin Infect Dis 2001;32:E131-136. doi: 10.1086/320149.

[112] Paramesh AS, Husain SZ, Shneider B, Guller J, Tokat I, Gondolesi GE, et al. Improvement of hepatopulmonary syndrome after transjugular intrahepatic portasystemic shunting: case report and review of literature. Pediatr Transplant 2003;7:157-162. doi: 10.1034/j.1399-3046.2003.00033.x.

[113] Gupta S, Faughnan ME, Lilly L, Hutchison S, Fowler R, Bayoumi AM. Norfloxacin Therapy for Hepatopulmonary Syndrome: A Pilot Randomized Controlled Trial. Clin Gastroenterol Hepatol 2010;8:1095-1098.

[114] Chevallier P, Novelli L, Motamedi JP, Hastier P, Brunner P, Bruneton JN. Hepatopulmonary syndrome successfully treated with transjugular intrahepatic portosystemic shunt: a three-year follow-up. J Vasc Interv Radiol 2004;15:647-648. doi: 10.1097/01.RVI.0000127885.68272.E9.

[115] Boyer TD, Haskal ZJ. The Role of Transjugular Intrahepatic Portosystemic Shunt (TIPS) in the Management of Portal Hypertension: update 2009. Hepatology 2010;51:306. doi: 10.1002/hep.23383. 